\title{
MID-HOLOCENE DATES FOR ORGANIC-RICH SEDIMENT, PALUSTRINE SHELL, AND CHARCOAL FROM SOUTHERN IRAQ
}

\author{
Carrie Hritz ${ }^{1}$ Jennifer Pournelle ${ }^{2}$ Jennifer Smith ${ }^{3}$ Badir Albadran ${ }^{4}$ Bushra Majeed Issa ${ }^{5}$ \\ Adil Al-Handal ${ }^{6}$
}

ABSTRACT. We present the results of accelerator mass spectrometry (AMS) radiocarbon dating of 11 samples collected from 4 locations in southern Iraq. As a result of the hiatus in fieldwork in that region since 1990, and the antiquity of the majority of archaeological excavations conducted there, the record of ${ }^{14} \mathrm{C}$ dates for southern Mesopotamia is patchy for all periods. This is especially true for the mid-Holocene, when the world's oldest and longest-sustained urban system first emerged there. The dates here reported not only make a significant contribution to available dates for this important region and period; they fill specific gaps in crucial geographic coverage, and shed light on the extent of marshland boundaries and the antiquity of settlement at key urban centers.

\section{INTRODUCTION}

Although the rise of the earliest cities in the ancient world has long been linked to successful exploitation and development of the 2 economic pillars of (especially grain) agriculture and (especially quadruped) animal husbandry, the relative contributions of other biotic resources to enabling or constraining urban inception, growth, and long-term sustainability remain relatively unexplored. This includes the nature, extent, and change through time of the underlying resource base of the marshes that fed and fueled the large populations that flocked to the nascent city-states of southern Mesopotamia, and the ecological effects, boundaries, and timeliness of mid-Holocene marine incursions and retractions. Despite 7 decades of excavation, remarkably little paleoenvironmental or paleoecological data associated with sites or derived from their local contexts has been collected for any period, including the crucial 'Ubaid-Uruk periods of the 5th-4th millennia, when Mesopotamian civilization was founded. Further, recent evidence from northern Mesopotamia (modern Syria) has produced an absolute chronology that cannot be reconciled with that of southern Mesopotamia until that chronology is anchored with absolute dates (Ur 2010; Pournelle and Algaze 2012).

For example, to date, only 3 limited coring operations have investigated the geomorphology of the southern Mesopotamian plain for this crucial formative period. At Uruk, presumably the oldest and largest city of its time, 2 borings penetrated to the marshy base on which the city was founded, suggesting that at its inception Uruk straddled the toes of an archaic distributary "bird's foot" delta debouching into a littoral zone (Brückner 2003:243; Pournelle 2003a,b, 2007: Figure 13). Supporting this hypothesis are analyses of a handful of cores drawn from southern Iraq and southwestern Iran, used to estimate the extent and timing of marine incursion and withdrawal at the head of the Arab-Persian Gulf from 8000 cal BP to the present (Larsen 1975; Aqrawi 2001; Gasche 2004; Pournelle 2006-2011; Heyvaert and Baeteman 2008).

\footnotetext{
${ }^{1}$ Department of Anthropology, The Pennsylvania State University, University Park, Pennsylvania 16801, USA. Corresponding author. Email: cah52@psu.edu.

${ }^{2}$ Environment and Sustainability Program, University of South Carolina, 901 Sumter St. Byrnes 430A, Columbia, South Carolina 29169, USA.

${ }^{3}$ Department of Earth and Planetary Sciences, Washington University in St. Louis, Campus Box 1169, 1 Brookings Dr., St. Louis, Missouri 63130, USA.

${ }^{4}$ Department of Geology, College of Science, University of Basrah-Qarmat Ali, Basra, Iraq.

${ }^{5}$ Department of Geology, College of Science, University of Basrah-Qarmat Ali, Basra, Iraq.

${ }^{6}$ Marine Sciences Centre, College of Science, University of Basrah-Qarmat Ali, Basra, Iraq.
} 
The samples reported herein represent a first-round attempt not only at bracketing timelines for these landscape changes, but establishing their relationship to key archaeological sites—one set dating to the period of early villages and preliterate societies (Eridu), and another to a thriving, literate Sumerian city (Girsu). Because the few other published mid-Holocene dates are scattered across various specialist publications, and over time have become inconsistent in their calibrations, for ease of comparison we also summarize those in Table 1, and indicate their extraction locations in Figure 3.

\section{METHODS}

\section{Archaeological Samples}

\section{Tell Abu Shahrain (Eridu): Shell}

Tell Abu Shahrain or ancient Eridu, one of the earliest permanent settlements in southern Iraq, is a 40-ha site, including a 20-ha mound and 12-ha acropolis, located in a topographic basin. Excavated in the 1940s, its occupation spans at least the 5th-2nd millennia BC, having reached its maximum area in the early 4th millennium BC. The excavations revealed a series of temples showing the development and transition of this hallmark of Mesopotamian architecture from a small votive complex, to what came to be considered as the first Sumerian city. Finds included nets and weights, bales of dried fish, and a canoe model interpreted as reflecting fishing in the marshes or coastal waters (Safar et al. 1981). This site holds the potential to provide evidence for the role of marsh and deltaic ecotones in 6th-5th millennium BC settlement establishment and expansion.

At each sample location (Figure 1), using aluminum forceps, J Pournelle collected $\sim 100 \mathrm{~g}$ of fossil shell, from the most common genera found in association with cultural material on the surface (denuded mudbrick: EP3-1-EP3-3; denuded mudbrick and pottery sherds, EP3-4). Each sample was wrapped in aluminum foil and sealed in a hard plastic sample bottle. One sample was collected offsite from modern ditch-digging upcast as a control. J Smith made preliminary identification of shell in the field. J Pournelle confirmed identification in the lab using 2 independent, locally derived identification keys (Plaziat and Younis 2005; Al-Ali 2007). The sample set was shipped to the NSF-University of Arizona AMS Laboratory with instructions to select best-possible subsamples for accelerator mass spectrometry (AMS) dating, maintaining common species across samples.

The lab chose suitable specimens of Melanoides tuberculata from each sample, including the control. Samples were pretreated with an acid-base-distilled water wash to remove surface residue, followed by selective dissolution (Burr et al. 1992). Pretreated samples were dissolved by phosphoric acid and $\mathrm{CO}_{2}$ collected in known volume for conversion to carbon monoxide over hot zinc, followed by conversion to graphite over hot $\left(600^{\circ} \mathrm{C}\right)$ iron.

\section{Tello (Girsu): Charcoal}

Tello or ancient Girsu is a 400-ha site located along the Shatt al-Gharraf River (Figure 1). It was one of 3 cities that comprised the 3rd millennium BC city-state of Lagash. Although known primarily from tablets and museum objects removed without recorded context during illicit and patchy excavations, the site clearly played an important role in the political landscape of Sumerian city-state system. If a way can be found to recontextualize previously excavated material, this site holds high potential for testing models regarding the development of urban hinterlands in conjunction with the rise of early cities.

While inspecting a 3-m-deep cut into an exposed profile of the Tell de la Maison des Fruits (Parrot 1948), J Smith and our SBAH (Iraq State Board of Antiquities and Heritage) representative noted 

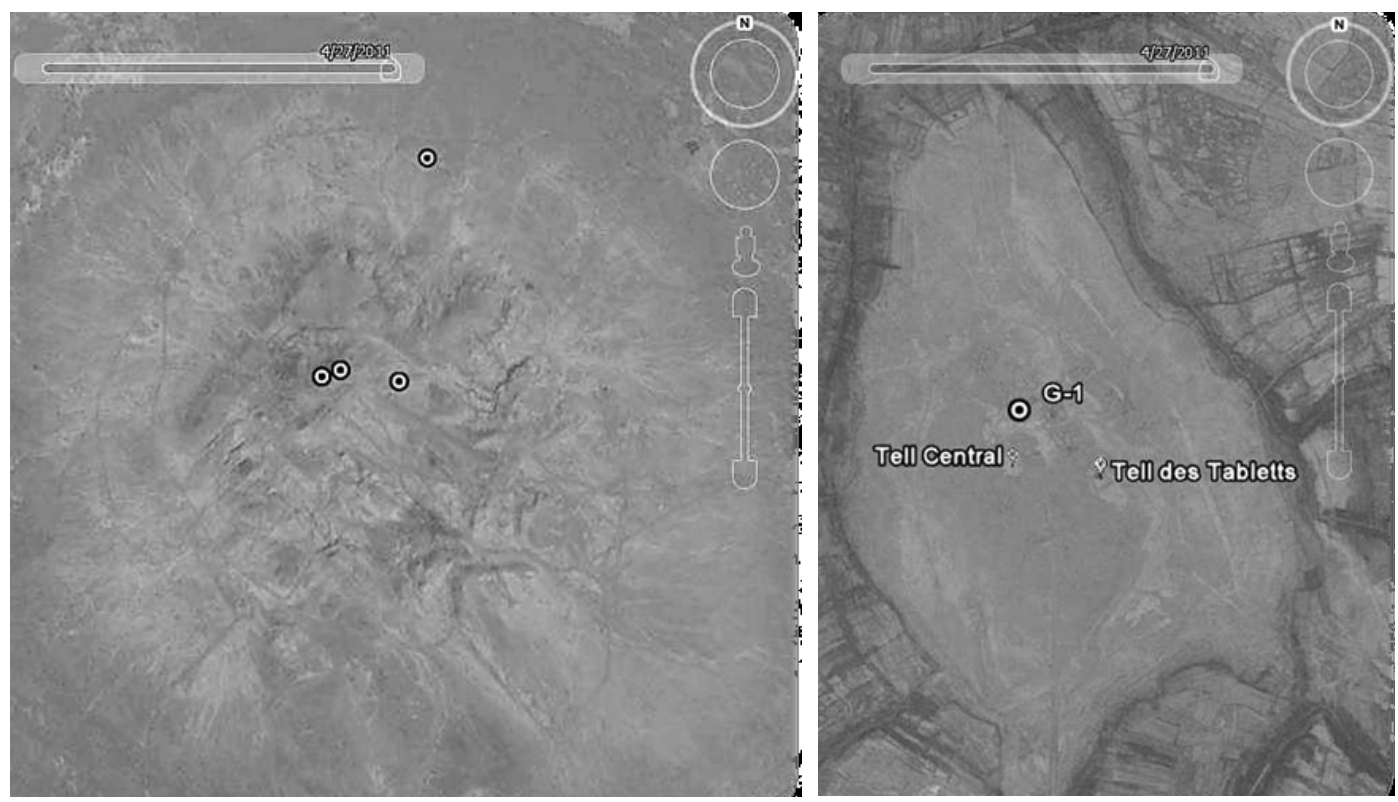

Figure 1 Sample collection points at Eridu (left) and Girsu (right). Photos $\subset$ Google Earth® 2011.

what appeared to be an inclined ash lens visible $2.15 \mathrm{~m}$ below the mound surface. Carbonaceous material was additionally concentrated on a moderately well-defined surface at that level. The representative suggested that we clean the section sufficiently to determine whether it might be possible to extract carbonized material for dating. Smith and Hritz extracted visible charcoal from the cleaned trench wall using a trowel, and stored it in aluminum foil. The charcoal was shipped to the University of Georgia Center for Applied Isotope Studies (CAIS). Pretreatment involved immersion in 5\% $\mathrm{HCl}$ at $80^{\circ} \mathrm{C}$ for $1 \mathrm{hr}$, washing with deionized water and rinsing with diluted $\mathrm{NaOH}$. The sample was then treated with diluted $\mathrm{HCL}$, washed, and dried at $60^{\circ} \mathrm{C} . \mathrm{CO}_{2}$ was produced from the cleaned sample by combustion in the presence of $\mathrm{CuO}$ at $900{ }^{\circ} \mathrm{C}$ in evacuated $I$ sealed ampoules. The resulting $\mathrm{CO}_{2}$ was cryogenically purified and converted to graphite following Vogel et al. (1984). Georgia's CAIS $0.5 \mathrm{MeV}$ accelerator mass spectrometer was used to measure graphite ${ }^{14} \mathrm{C} /{ }^{13} \mathrm{C}$ ratios. The sample ratios were measured against the oxalic acid I (NBS SRM 4990) standard. The date given was corrected for fractionation using ${ }^{13} \mathrm{C} /{ }^{12} \mathrm{C}$ ratios measured with a stable isotope ratio mass spectrometer against the PDB standard (Donahue et al. 1990). This date is given in radiocarbon years before 1950 (yr BP), using the ${ }^{14} \mathrm{C}$ half-life of $5568 \mathrm{yr}$. The error, quoted as 1 standard deviation, reflects both statistical and experimental errors. The calibrated dates are reported as $2 \sigma$ ranges.

\section{Sediment Samples}

The marshes of southern Iraq were once the largest marshland in western Asia (Chen et al. 2010). The Hammar Basin lies west of the Shatt el Arab and south of the Euphrates River, extending west almost to Nasiriya; predrainage lacustrine (Hawr al Hammar) and marshland environments covered from 28,000 (perennially) to 45,000 (seasonally) $\mathrm{km}^{2}$ (IMOS 2006). The marshland is dominated by extensive reedbeds and mudflats. The basin itself is thought to result from tectonic subsidence and/ or compaction of fluvio-deltaic sediments (Aqrawi et al. 2006). Much of the area that was once under permanent or seasonal water was exposed by drainage activities in the 1990s; thus, the ground surface now in many places is desiccated, with reed casts and gastropod shells littering the surface. 


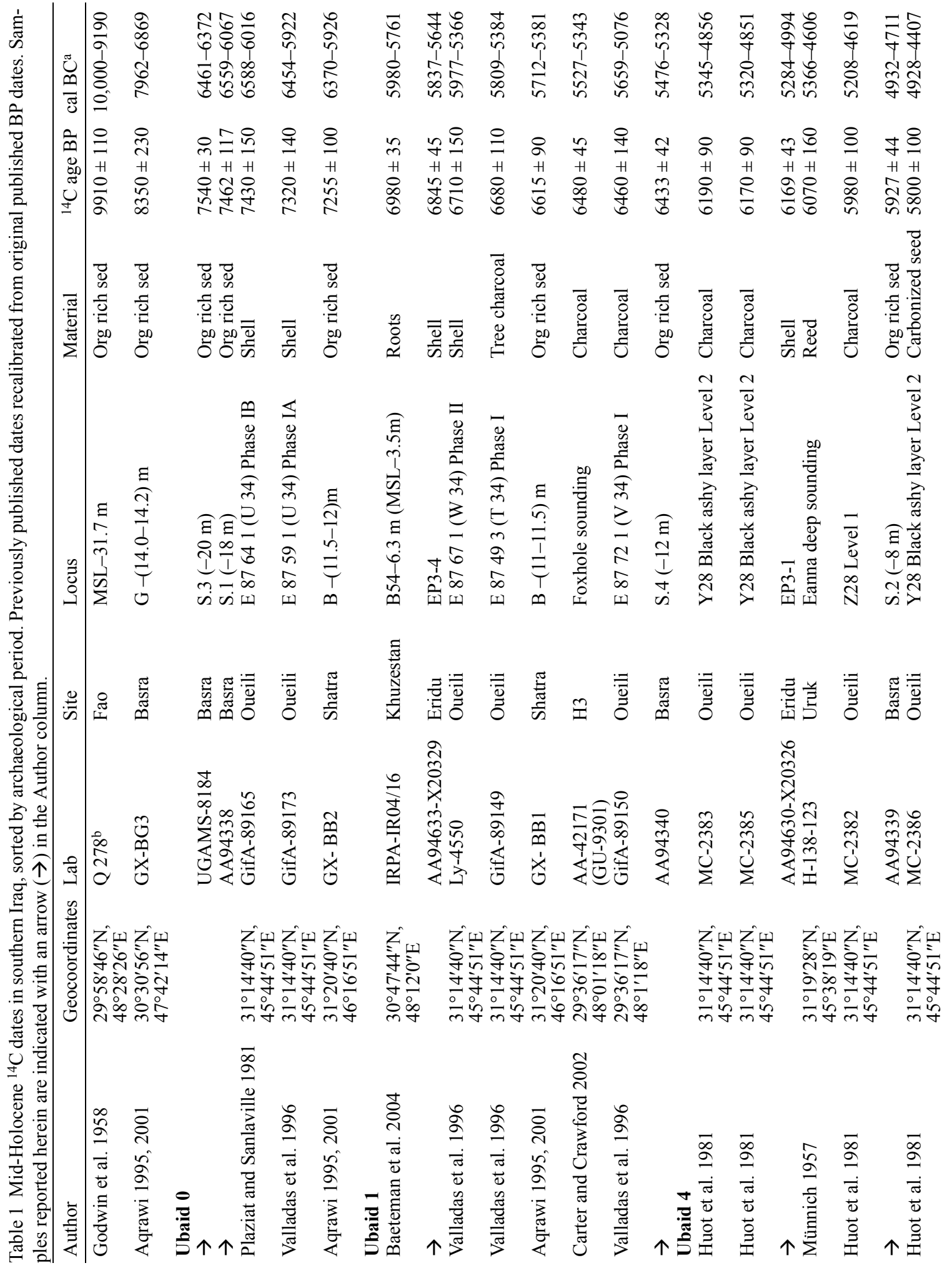




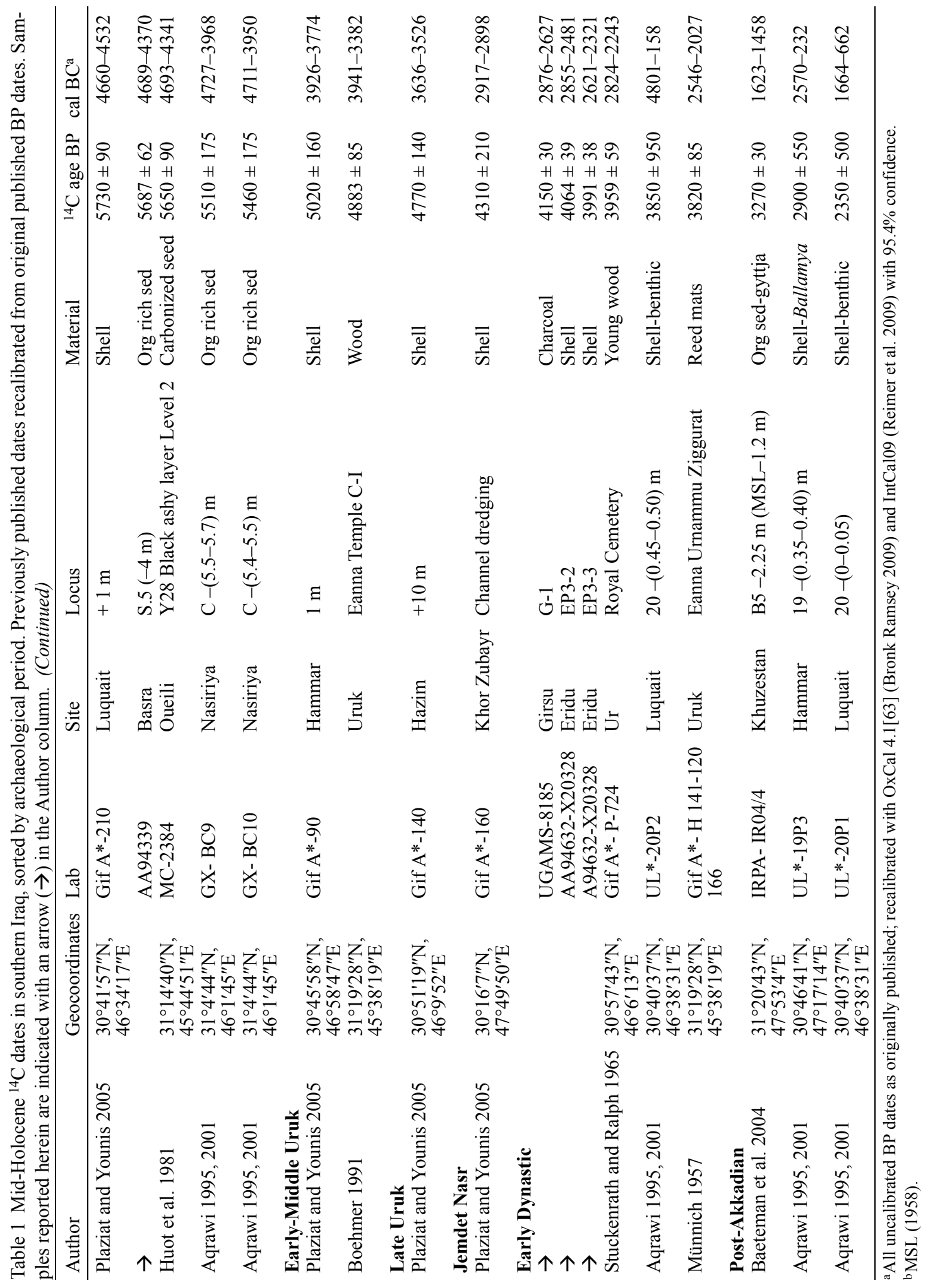


One core was taken from a borehole near the Shatt al-Arab river in the city of Basra (samples S.1S.5). A second was taken by hand auger from the shore of the Shatt el-Arab estuary near Fao $(\mathrm{F} 35 \mathrm{~cm})$. Cores were split and subsampled at the University of Basrah, with subsamples S.1-S.5 stored in aluminum foil and frozen within $24 \mathrm{hr}$ of sample acquisition. Sample F $35 \mathrm{~cm}$ was stored at room temperature. One sample (S.3) was shipped to the University of Georgia Center for Applied Isotope studies and 5 samples (S.1, S.2, S.4, S.5, and F35cm) were shipped to the NSF-University of Arizona AMS facility.

\section{Basra and Fao: Organic-Rich Sediment}

Sample S.3 was pretreated with $5 \% \mathrm{HCl}$ and washed following the procedure outlined for the charcoal sample, without a second $\mathrm{HCl}$ treatment. The recovered carbon dioxide was cryogenically purified and converted to benzene on V-Al-Si catalyst. The activity of the sample was measured on a Packard Tri-Carb 1050 liquid scintillation analyzer and reported as ${ }^{14} \mathrm{C}$ age. Correction for isotope fractionation and reporting of the date and associated error was performed as described above for the Tello charcoal sample. Pretreatment of samples at the NSF-Arizona AMS facility followed published protocols (Jull et al. 2006).

\section{RESULTS}

Extraction locations for all samples are depicted at Figure 3.

\section{Archaeological Samples}

\section{Tell Abu Shahrain (Eridu): Shell}

\section{$6845 \pm 45$ BP [(IntCal09) cal 5837-5644 BC]}

AA94633-X20329. Eridu, north base of mound, EP3-4 $\quad \delta^{13} \mathrm{C}=3.3 \%$ Fossil Melanoides tuberculata shell, selected from a rich shell assemblage also including Melanopsis, Unio, and Anandata sp. intermixed with (possibly 'Ubaid 2/3) pottery (Figure 2), gypsiferous lumps of mortar or plaster, and dark, soft, reddish dry mud, near the base of the stratified tell at a point $\sim 3 \mathrm{~m}$ above plain level. Soil color and location are consistent with descriptions of the earliest part of the mound (Safar et al. 1981), and inconsistent with the gray, crusted, water-laid silts that result from seasonal inundation at plain level. The assemblage of shell, mudbrick fragments, and cultural material is therefore presumed to be denuded mudbrick. Shell assemblage is typical of quiet, shallow lake bottoms in this region, but not of seasonal sheetwater or flowing canals (Plaziat and Younis 2005); from Tel Abu Shahrain (Eridu), Dhi Qar Governourate, $36 \mathrm{~km}$ southwest of Nasiriyah $\left(30^{\circ} 49^{\prime} 8.49^{\prime \prime} \mathrm{N}, 45^{\circ} 59^{\prime} 46.67^{\prime \prime} \mathrm{E}\right)$. Collected and submitted in 2011 by J R Pournelle.

Comment: This date provides a minimum age for freshwater marsh/lake formation in the vicinity of Eridu. Date overlaps 'Ubaid $1{ }^{14} \mathrm{C}$ dates at Tell al-Oueili (Valladas et al. 1996; see Table 1). Therefore, the muds used for construction were presumably laid down $\sim 500 \mathrm{yr}$ before mudbrick construction in this area, as indicated by the Ubaid 2/3 potsherds also presumably incorporated into the nowdenuded mudbrick (Figure 4, right). This would be consistent with workers hand-digging surface clays up to $\sim 1 \mathrm{~m}$ depth (see samples C-1 and EP3-3). Small sherds visible on the surface exhibited ware and decoration that are consistent with Ubaid 2/3 (Figure 2); possibly as early as 'Ubaid 1. We could not conduct formal collection for diagnostic sherds as we did not have formal archaeological survey permission. 


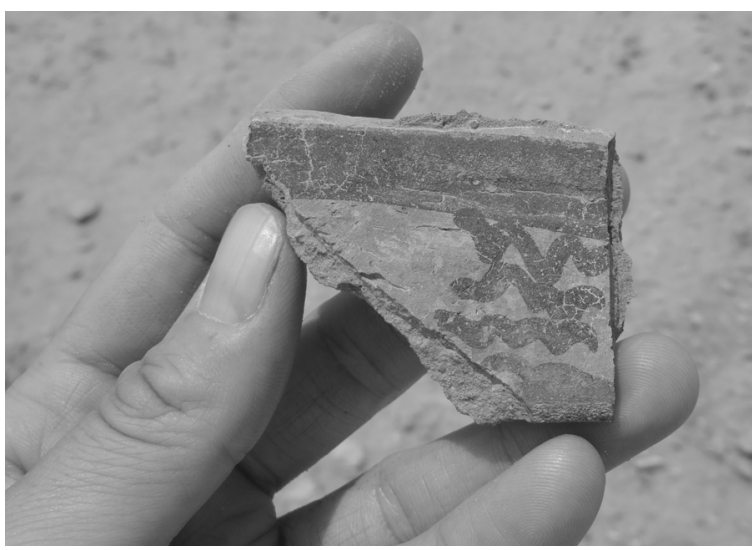

Figure 2 'Ubaid 2/3 pottery sherd at Sample EP-3 collection point. Photo C A Hritz 2010.

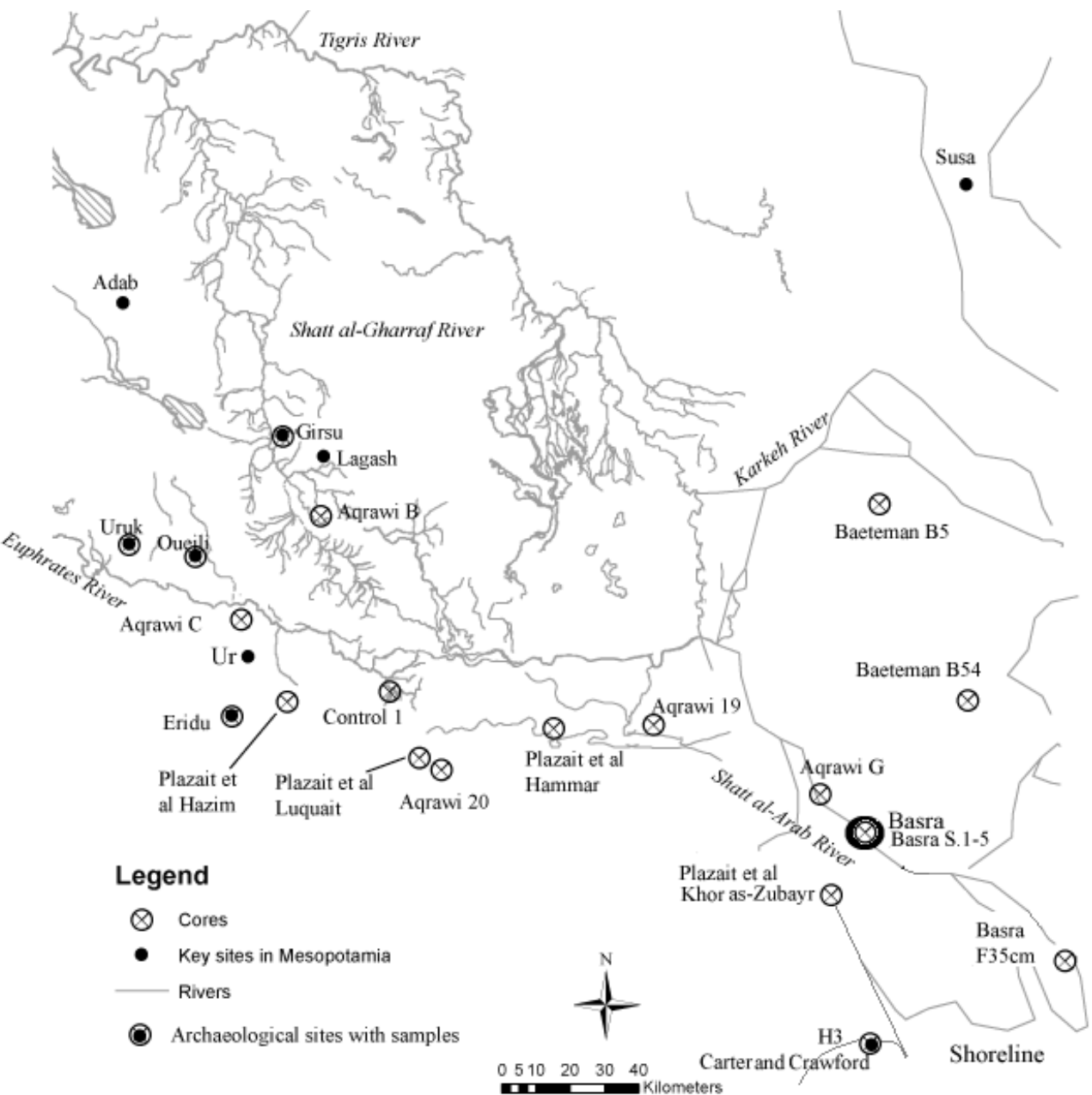

Figure 3 Dated ${ }^{14} \mathrm{C}$ sample locations in southern Iraq and Khuzistan 

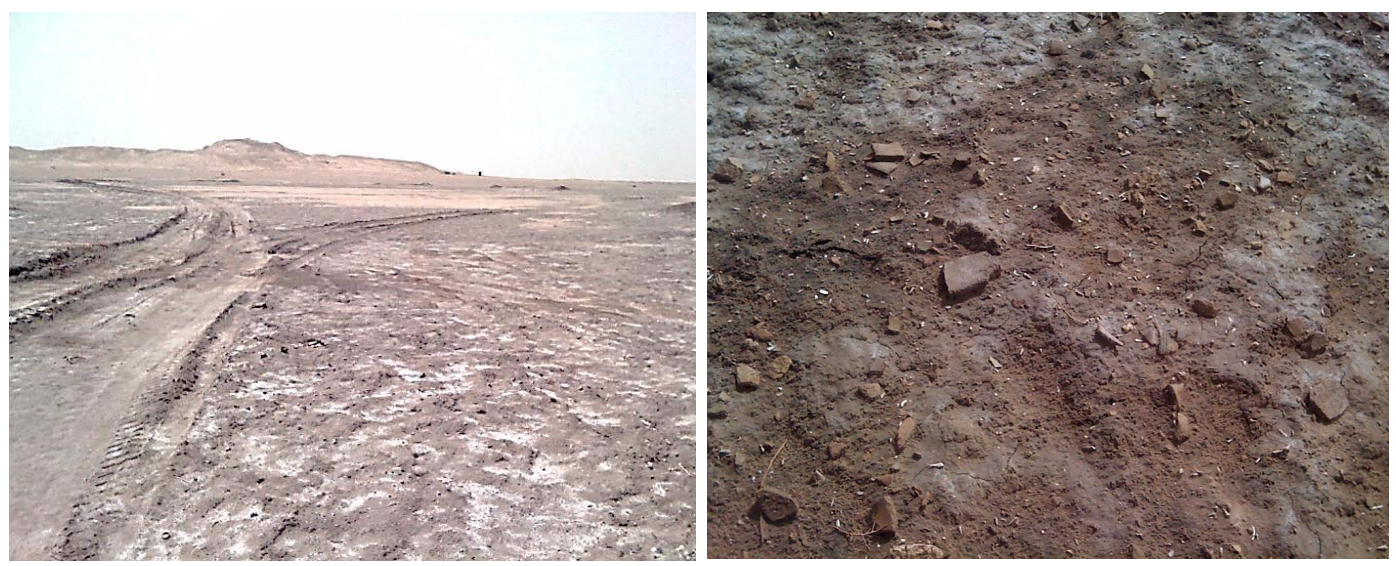

Figure 4 Eridu. (Left) Vehicle tracks to the high mound. Note the ruts - this area is often inundated with sheetwater following rains. Note also the gypsiferous evaporates visible as white surface salts, and the near-absence of surface shell. Arrows indicate sample collection points. (Right) Collection point for sample EP-4, 2-3 m above the floodplain. Note the dense admixture of shell, pottery sherds, and brick fragments, typical of denuded mudbrick. Note also the absence of any crusted silt, plant fragments, or reed casts that would be consistent with recent inundation.

\section{$6169 \pm 43$ BP [(IntCal09) cal 5284-4994 BC]}

\section{AA94630-X20326. Eridu, center of main mound, EP3-1}

$\delta^{13} \mathrm{C}=5.9 \%$

Fossil Melanoides tuberculata shell, extracted from a low mound of denuded libn (mudbrick) rich with shell (also including Melanopsis and Unio sp.). Possibly excavation spoil, but away from any obvious spoil heaps or trafficked areas, in a flat area near the center of the main mound, elevated $\sim 9 \mathrm{~m}$ above plain level, $42 \mathrm{~m}$ east of the ziggurat. Shell assemblage typical of shallow lakes in this region (Plaziat and Younis 2005). From Tel Abu Shahrain (Eridu), Dhi Qar Governorate, $36 \mathrm{~km}$ southwest of Nasiriyah $\left(30^{\circ} 49^{\prime} 2.79^{\prime \prime} \mathrm{N}, 45^{\circ} 59^{\prime} 45.84^{\prime \prime} \mathrm{E}\right)$. Collected and submitted in 2011 by J R Pournelle.

Comment: This date provides a minimum age for persistence of freshwater marshes/lakes in the vicinity of Eridu. Date overlaps 'Ubaid $3 / 4{ }^{14} \mathrm{C}$ dates at Tell al-Oueili (Huot et al. 1981; Valladas et al. 1996; see Table 1).

\section{$4064 \pm 39$ BP [(IntCal09) cal 2855-2481 BC]}

\section{AA94632-X20328. Eridu, top of ziggurat, EP3-2}

$\delta^{13} \mathrm{C}=5.9 \%$

Fossil Melanoides tuberculata shell, on ground surface, from a flat area of denuded gray libn (mudbrick) pavement at the top of the ziggurat, rich with shell also including Melanopsis, elevated $\sim 12 \mathrm{~m}$ above plain level and near the center of the tell. From Tel Abu Shahrain (Eridu), Dhi Qar Governorate, $36 \mathrm{~km}$ southwest of Nasiriyah $\left(30^{\circ} 49^{\prime} 3.05^{\prime \prime} \mathrm{N}, 45^{\circ} 59^{\prime} 46.27^{\prime \prime} \mathrm{E}\right)$. Collected and submitted in 2011 by J R Pournelle.

Comment: Shell assemblage typical of freshwater marsh in this region (Plaziat and Younis 2005). Date overlaps an Early Dynastic I ${ }^{14} \mathrm{C}$ date from the "Royal Tombs" at Ur (Stuckenrath and Ralph 1965; see Table 1) and thus provides a minimum Early Dynastic I age for the continuing presence of freshwater marshes/lakes in the vicinity of Eridu. It is consistent with EP3-3, showing an overlapping maximum age range for the muds used to manufacture the libn at the top of the ziggurat. 
$3991 \pm 39$ BP [(IntCal09) cal 2621-2351 BC]

AA94632-X20328. Eridu, 3d brick tier near top of ziggurat, EP3-3 $\quad \delta^{13} \mathrm{C}=\mathbf{4 . 6 \%}$ Fossil Melanoides tuberculata shell, actively eroding from the third tier down of gray libn (mudbrick) near the top of the ziggurat, rich with shell, elevated $\sim 11 \mathrm{~m}$ above plain level on the southeast face of the ziggurat. From Tel Abu Shahrain (Eridu), Dhi Qar Governorate, $36 \mathrm{~km}$ southwest of Nasiriyah $\left(30^{\circ} 49^{\prime} 2.90^{\prime \prime} \mathrm{N}, 45^{\circ} 59^{\prime} 43.70^{\prime \prime} \mathrm{E}\right)$. Collected and submitted in 2011 by J R Pournelle.

Comment: Shell assemblage typical of salinity-tolerant species of freshwater marsh in this region may indicate that water was becoming more brackish (Plaziat and Younis 2005). Date overlaps Early Dynastic I ${ }^{14} \mathrm{C}$ dates at Ur (Stuckenrath and Ralph 1965) and Early Dynastic III ${ }^{14} \mathrm{C}$ dates at Uruk (Münnich 1957; see Table 1). It thus provides an Early Dynastic I-III age for the continuing presence of freshwater marshes/lakes in the vicinity of Eridu. This date is consistent with EP3-2, showing an overlapping maximum age range for the muds used to manufacture the libn at the top of the ziggurat. Ziggurat construction is attributed to Ur-Nammu, founder of the Third Dynasty of Ur (Ur III), who reigned 2047-2030 BC (short chronology). Therefore, the muds used were presumably laid down $\sim 700 \mathrm{yr}$ before construction of the ziggurat. This would be consistent with workers handdigging surface clays to approximately $1 \mathrm{~m}$ depth (see samples C-1 and EP3-4).

$718 \pm 35$ BP [(IntCal09) cal 1287-1380 AD]

\section{AA94634-X20330. Suq as-Shuyukh, C-1}

$\delta^{13} \mathrm{C}=7.2 \%$

Fossil Melanoides tuberculata shell, mixed with gray silt, recently upcast from $\sim 1 \mathrm{~m}$ below plain level by workers using hand tools to dig a ditch, rich with shell (also including Melanopsis, Bellamia, Lymnaea, and Corbicula sp.). From Suq as-Shuyukh, Dhi Qar Governorate, (30 $49^{\prime} 1.35^{\prime \prime} \mathrm{N}$, $\left.45^{\circ} 59^{\prime} 46.27^{\prime \prime} \mathrm{E}\right)$. Collected and submitted in 2011 by J R Pournelle.

Comment: This date provides a random, off-site control for the previous dates. It is consistent with Aqrawi (1995:414), who showed that fossil Melanoides shell at plain level from seasonally inundated areas in the Hammar district, subject to past eolian scouring, is of late Islamic age ( $\sim 400 \mathrm{yr}$ BP). The collection point for C-1, situated near the point of inflow of the modern Euphrates into the western Hammar marshes ( $\sim 90 \mathrm{~km}$ west of Aqrawi's collection area), is a locus of ongoing sediment deposition. The mollusk assemblage indicates that the silts were laid in quiet waters, not subject to significant sediment mixing (Plaziat and Younis 2005). The approximately 700 -yr-old age of these fossils, hand-dug from a depth of $\sim 1 \mathrm{~m}$, is consistent with: (1) The difference between fossil age and the accepted historical date of ziggurat construction at Eridu (samples EP3-2 and EP3-3); and (2) the difference between fossil age and mixed pottery fragments reported for sample EP3-4.

Tello (Girsu): Charcoal

$4150 \pm 30$ BP [(IntCal09) cal 2876-2627 BC]

UGAMS-8185. Girsu, G-1

$\delta^{13} \mathrm{C}=\mathbf{2 5 . 8 \%}$

10-g samples of fossil brushwood charcoal, from a sealed ash lens consistent with a household hearth, revealed in profile by a cut made by previous excavators into the Tell de la Maison des Fruits. From Tello (Girsu), Dhi Qar Governourate, $36 \mathrm{~km}$ northeast of Nasiriyah $\left(31^{\circ} 56^{\prime} 25.56^{\prime \prime} \mathrm{N}\right.$, $\left.46^{\circ} 17^{\prime} 71.78^{\prime \prime} \mathrm{E}\right)$. Collected in 2011 by J Smith and C Hritz and submitted by J Smith and J Pournelle.

Comment: This date provides a minimum age (Early Dynastic I) for a possibly intact settlement area that, if excavated, could provide context for early finds at Girsu. The date overlaps an Early Dynastic I ${ }^{14} \mathrm{C}$ date from the "Royal Tombs" at Ur (Stuckenrath and Ralph 1965; see Table 1). The location of this sample well above modern plain level and the bottom of the mound suggests significant earlier occupation at the site. 


\section{Sediment Samples}

Basra and Fao: Organic-Rich Sediment

$7540 \pm 30$ BP [(IntCal09) cal 6461-6372 BC]

UGAMS-8184. Basra, S.3

$\delta^{13} \mathrm{C}=25.2 \%$

200-g sample of organic-rich sediment extracted from a borehole core at $20 \mathrm{~m}$ below ground surface. From city of Basra $\left(30^{\circ} 30^{\prime} 58^{\prime \prime} \mathrm{N}, 47^{\circ} 50^{\prime} 20^{\prime \prime} \mathrm{E}\right)$. Collected in 2010 by B Issa and submitted by J Smith.

Comment: This date is consistent with depths for pre-Hammar Formation (marine transgression) fluvial peats at Basra, and marsh peats at Shatra (reported by Aqrawi and Evans 1994; Aqrawi 1995; Larsen 1975).

$7462 \pm 117$ BP [(IntCal09) cal 6559-6067 BC]

AA94338. Basra, S.1

$\delta^{13} \mathrm{C}=\mathbf{2 0 . 9 \%}$ 135-g sample of organic-rich sediment extracted from a borehole core at $18 \mathrm{~m}$ below ground surface. From city of Basra $\left(30^{\circ} 31^{\prime} 9.56^{\prime \prime} \mathrm{N}, 47^{\circ} 48^{\prime} 42.78^{\prime \prime} \mathrm{E}\right)$. Collected in 2010 by B Issa and submitted by J Smith.

Comment: This date is consistent with depths for pre-Hammar Formation (marine transgression) fluvial peats at Basra, and marsh peats at Shatra (reported by Aqrawi and Evans 1994; Aqrawi 1995; Larsen 1975).

\section{$6433 \pm 42$ BP [(IntCal09) cal 5476-5328 BC]}

AA94340. Basra, S.4

$\delta^{13} \mathrm{C}=15.9 \%$

200-g sample of organic-rich sediment extracted from a borehole core at $12 \mathrm{~m}$ below ground surface. From city of Basra $\left(30^{\circ} 31^{\prime} 9.56^{\prime \prime} \mathrm{N}, 47^{\circ} 48^{\prime} 42.78^{\prime \prime} \mathrm{E}\right)$. Collected in 2010 by B Issa and submitted by J Smith.

Comment: This date is consistent with depths for pre-Hammar Formation (marine transgression) fluvial peats at Basra, and marsh peats at Shatra (reported by Aqrawi and Evans 1994; Aqrawi 1995; Larsen 1975).

$5927 \pm 44$ BP [(IntCal09) cal 4932-4711 BC]

AA94339. Basra, S.2

$\delta^{13} \mathrm{C}=\mathbf{2 2 . 7 \%}$ 200 -g sample of organic-rich sediment extracted from a borehole core at $8 \mathrm{~m}$ below ground surface. From city of Basra $\left(30^{\circ} 31^{\prime} 9.56^{\prime \prime} \mathrm{N}, 47^{\circ} 48^{\prime} 42.78^{\prime \prime} \mathrm{E}\right)$. Collected in 2010 by B Issa and submitted by J Smith.

Comment: This date is consistent with depths for post-Hammar Formation (marine transgression) fluvial peats at Basra, and pre-Hammar Formation marsh peats at Nasriya and Shatra (reported by Aqrawi and Evans 1994; Aqrawi 1995; Larsen 1975).

$5687 \pm 62$ BP [(IntCal09) cal 4689-4370 BC]

AA94339. Basra, S.5

$\delta^{13} \mathrm{C}=\mathbf{2 1 . 3 \%}$ 200-g sample of organic-rich sediment extracted from a borehole core at $4 \mathrm{~m}$ below ground surface. From city of Basra $\left(30^{\circ} 31^{\prime} 9.56^{\prime \prime} \mathrm{N}, 47^{\circ} 48^{\prime} 42.78^{\prime \prime} \mathrm{E}\right)$. Collected in 2010 by B Issa and submitted by J Smith.

Comment: This date is consistent with depths for post-Hammar Formation (marine transgression) fluvial peats at Basra, and pre-Hammar Formation marsh peats at Nasriya (reported by Aqrawi and Evans 1994; Aqrawi 1995; Larsen 1975). 
Post-Bomb

AA94342- X20126. Fao, F35cm

$\delta^{13} \mathrm{C}=23.1 \%$

200-g sample of organic-rich sediment extracted from a hand-augered core at $0.35 \mathrm{~m}$ below ground

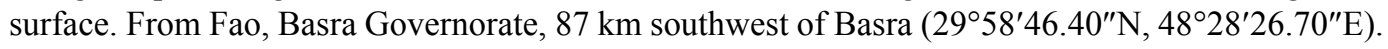
Collected in 2010 by A Handal and submitted by J Smith.

Comment: This date provides a control for shallow surface sediments from a location known to have been fully submerged during the mid-Holocene.

\section{DISCUSSION}

\section{Shell Samples}

\section{Reservoir Effects}

We have not applied marine reservoir or hardwater effect corrections to reported dates (Southon et al. 2002) for the following reasons. First, within the region, the shell assemblage from which we extracted the samples is typical of palustrine, not marine, environments. Second, although carbonate outcrops (of Euphrates limestone) are evident within the broader region, none are located within $100 \mathrm{~km}$ of Eridu; therefore, the contribution of dead carbon from these sources it not likely to have significantly affected the water bodies in which sampled gastropods lived. Third, corrections based on recent pre-bomb specimens were not possible, as any specimens collected by the universities of Basrah and Baghdad prior to 1950 were destroyed during looting of those institutions following the 2001 Gulf War. Fourth, because the area is now desiccated, no live specimens were available for collection within $30 \mathrm{~km}$ of the site. Finally, only 3 benthic marine samples have been recorded for the Arab-Persian Gulf: 2 from Muscat and 1 from Qatar. The calculated reservoir effect based on those samples is only $\pm 31 \mathrm{yr}\left({ }^{14} \mathrm{CHRONO}\right.$ Centre 2011$)$. The 2 Pinctada (oyster) and 1 Marcia (clam) species included in that calculation are estuarine filter-feeders, and therefore during life are less likely to be significantly impacted by old carbon from deep-water upwelling than genuinely marine species. Melanoides, a short-lived grazer, would have even less exposure.

\section{Collection Method and Context}

No samples were collected from the water-laid gray silts that surround the entirety of the Eridu mound as a result of recent and past seasonal surface flooding. All samples were collected from well above the floodline of the inundation zone. M. tuberculata were chosen across all samples for dating in order to provide a consistent species (and thus consistent biological processes for carbon uptake) across our own and Aqrawi's samples. However, we must stress that M. tuberculata was neither the only species present, nor the index species used to characterize local conditions. $M$. tuberculata alone may indicate virtually any kind of wet environment, while the total assemblage of shells from which each $M$. tuberculata shell was selected for dating does not occur as a result of seasonal inundation alone. The assemblage includes non-riparian, draught-intolerant organisms and is more correctly indicative of explicitly still-water lacustrine conditions.

In keeping with site conservation requirements, we did not conduct destructive sampling (e.g. fracturing mudbrick to obtain specimens from the interior). Sample EP3-3, embedded in a mudbrick surface, but clearly about to fall out as a result of natural weathering, was plucked from a vertical exterior mudbrick face (Figure 4). Samples EP3-1 and EP3-2 were extracted from recently denuded mudbrick, as indicated by both having fallen (a few centimeters) into a crumbled pile, mixed with recently loosened mud, at the base of a stump of a rain-soaked, weathered mudbrick face. Sample EP3-4 was collected from a mixture of mudbrick fragments, pottery fragments, mortar fragments, 
and soft, dried dark, reddish mud, consistent with the texture and color of denuded mudbrick in this area of the site, but inconsistent with the water-laid gray silts that encrust the plain level several meters below the mound.

The most parsimonious explanation to account for a shell assemblage, typical of a perennial lacustrine environment, and atypical of seasonal inundation, actively eroding from mudbrick at all levels of the mound, beginning $3 \mathrm{~m}$ above the high-stand flood line, in sufficient quantity to cover the entire mound up to the top of the ziggurat (which stands $13 \mathrm{~m}$ above plain level), is that the shell was a component of the mud used to manufacture mudbrick at the time of construction. If we also presume that mud to have been locally dug from silt (rather than scraped from an active surface layer containing living organisms), we would also expect any shell sample to predate brick manufacture and construction, since the organism it housed would have died, decomposed, and been incorporated into the silt bed prior to being dug from local clay pits (Wilkinson 2003:110). This expectation is consistent with our findings for all samples, including our external control.

\section{Charcoal Sample}

While providing only a single date, the charcoal sample collected from the Tell de la Maison des Fruits at Girsu is significant for a number of reasons. Parrot's excavations at the turn of the 20th century were extremely destructive (the methods used would, today, be indistinguishable from looting), and entirely focused on obtaining objects for museums and private collections. The site was left pitted with craters tens of meters wide and deep, undermined by tunnels, and covered with massive mounds of dumped spoil. The subsequent publications were little more than artifact lists, with no context provided for any of the objects, and no independent dating methods applied. Such dates as were offered for the various finds were ascribed by the excavators on stylistic grounds, and then "dated" by putative relation to historical texts. Thus, it was long thought that recorrelation of the considerable corpus of material from Girsu to any archaeological context would be impossible. However, discovery of the ashy lens from which we collected our sample, which was situated atop at least $5 \mathrm{~m}$ of apparently undisturbed cultural material, holds out promise that test excavations here, planned for the near future, could reveal an intact settlement area that may provide context for early finds as well as a window into earlier periods.

Until now, only 2 Early Dynastic ${ }^{14} \mathrm{C}$ dates have ever been derived from any archaeological context in the southern alluvium: one from Ur, collected in 1965, and one from Uruk, collected in 1957. This is, to say the least, an insufficient basis for correlation of archaeologically and historically derived dates. Because our Girsu date overlaps both the Early Dynastic I ${ }^{14} \mathrm{C}$ date from the "Royal Tombs" at Ur (Stuckenrath and Ralph 1965; see Table 1), and the 2 AMS dates reported herein for the muds used to build the ziggurat at Eridu, future excavations at Girsu may allow for genuinely synchronic comparisons among these major sites.

Finally, this date demonstrates that we have successfully bracketed, both temporally and spatially, the period of urban genesis in which we are especially interested, and that we have developed a successful methodology for rapidly collecting relevant data across multiple sites, in order to begin filling in that sequence.

\section{Sediment Samples}

The 20-m core was drawn from inside the Basra city limits, within the Shatt al-Arab Valley. The 5 samples of organic-rich sediments were extracted from sections that, on visual inspection, appeared to have high organic content, in order to obtain initial bracket dates for the top, middle, and bottom of the core. The organic-rich sediments are not continuous from the bottom to the top of the core. 
Therefore, these discrete samples indicate only active peat formation within the Shatt al-Arab Valley at the specific dates indicated. A complete core profile and analysis is underway and will be published when complete.

The primary significance of these early results is that these AMS dates are, thus far, consistent with Aqrawi Core G, also drawn from Basra (see Figure 3). This helps to validate and add precision to Aqrawi's previously published dates (see Table 1), despite the time passed since their collection, the fact that they were ${ }^{14} \mathrm{C}$ (not AMS) dated, and their having been processed at different facilities using unknown sample preparation protocols.

Thus, while we do not yet know whether these are fluvial or marsh sediments, if further findings prove consistent with Aqrawi and Evans (1994) and Larsen (1975), we would we expect the former for samples S.1, S.3, and S.4, and the latter for samples S.2 and S.5. We would also expect to see a marine incursion layer below samples S.2 and S.5, with layering of intermixed and reworked fluvial-laid silts and riparian peats before, after, and between samples in the series.

\section{Other Published Dates in Region}

Locations for previously published mid-Holocene dates for the region are depicted in Figure 3 and summarized in Table 1. To ensure transparent comparison among data sets, compiled and published across 3 decades using varying calibration curves, we have recalibrated all published uncalibrated $\mathrm{BP}$ dates to calibrated BC/AD dates using IntCal09 (Reimer et al. 2009). The primary data sets include: wooden bucket handles from Ur (Stuckenrath and Ralph 1965); wood (Boehmer 1991), reed (Münnich 1957); and organic sediments (Fassbinder et al. 2005) collected at various times by the German Archaeological institute at Warka (Uruk); carbonized seed, shell, and tree charcoal excavated from Tell al-Oueili during the 1980s (Huot et al. 1981; Valladas et al. 1996); organic-rich sediments and shell collected from 9 locations spanning the former southeastern marshlands known as the Awhar, also during the 1980s (Aqrawi 1995:414; Plaziat and Younis 2005:2); 2 corings from neighboring Khuzistan (Baeteman et al. 2004/2005) and charcoal from site H-3 (Tell As-Sabiyah) in Kuwait (Carter and Crawford 2002). Also relevant in this context are dates for river channels in the vicinity if Sippar, at the head of the lower Mesopotamian alluvium, which anchor mid-Holocene freshwater discharges into the southern deltaic system (Heyvaert and Baeteman 2008). Wright and Rupley (2001) summarize published dates for sites in northern Mesopotamia (see also Oates et al. 2007).

\section{CONCLUSIONS}

These 11 samples, plus the recalibration to the same standard of all prior samples published for this region, shed light our understanding of the environment of southern Mesopotamia and the development of complex society there in the following ways:

First, they fill in the spatial gaps in the patchy paleoenvironmental record. Second, they can be used as base data sets to link absolute chronological dates from northern and southern Mesopotamia. Third, the dates from the site of Eridu provide empirical evidence for the interpretation of archaeological material collected at the site and the outline of the landscape surrounding it (Wright and Rupley 1981). The 5 samples, including the control sample, demonstrate the existence and persistence of a marshy environment around the site from its first settlement in the late 6th millennium $\mathrm{BC}$, through the period of the development of the first cities in southern Iraq and into the latter 3rd millennium BC. Fourth, the single sample from Girsu demonstrates the potential for AMS dating methods to provide new information from sites that have faced destruction, and provides insight into the taphonomic processes of site preservation. Further, the presence of the sample several meters above plain 
level speaks to a long occupation, once inferred but not demonstrated, at this site. Finally, as do the Eridu samples, the samples from Basra provide a crucial contemporary comparator for previous dates, verifying and refining previous archaeological and particularly geological work in the region.

\section{ACKNOWLEDGMENTS}

The authors are grateful for support of this work from NSF-HRRPAA Award \# 1045974. Statements of fact, opinions, conclusion, and errors are solely those of the authors, and do not express or imply endorsement by the National Science Foundation. We are also indebted to the Iraq State Board of Antiquities and Heritage (SBAH) and the Iraq Ministries of Culture, Interior, and Tourism, for granting us permission to visit sites and complete collection. We are especially thankful to SBAH Director Quais Hussein Rasheed, and SBAH representatives from Dhi Qar and Nasiriya for their support; Sheikh 'Ali ibn Muhammed al-Ghizi and Dhaif Muhsen Al-Ghizi, Site Curator of Ur, for their hospitality, support, and guidance; to the Iraq Ministry of the Interior for providing police escorts within each governorate and city district; and to 3 unidentified reviewers for their constructive comments. The principals and staff of Babel Tours Iraq provided excellent facilitation, logistical support, and transportation.

\section{REFERENCES}

${ }^{14}$ CHRONO Centre, Queens University Belfast. Marine Reservoir Correction: Subregion Arabian-Persian Gulf. http://radiocarbon.pa.qub.ac.uk/marine/regioncalc.php. Accessed 29 September 2011.

Al-Ali R A-S. 2007. Study of recent faunal assemblages and their ecology in the northwestern Arabian Gulf and Southern Mesopotamia [unpublished PhD dissertation]. University of Basrah.

Aqrawi A. 1995. Correction of Holocene sedimentation rates for mechanical compaction: the Tigris-Euphrates Delta, lower Mesopotamia. Marine and Petroleum Geology 12(4):409-16.

Aqrawi AAM. 2001. Stratigraphic signatures of climatic change during the Holocene evolution of the TigrisEuphrates Delta, lower Mesopotamia. Global and Planetary Change 28(1-4):267-83.

Aqrawi AAM, Evans G. 1994. Sedimentation in the lakes and marshes (Awhar) of the Tigris-Euphrates Delta, southern Mesopotamia. Sedimentology 41(4):755-76.

Aqrawi AM, Domas J, Jassim SZ. 2006. Quaternary deposits. In: Jassim SZ, Goff JC, editors. Geology of Iraq. Praque: Dolin. p 185-96.

Baeteman C, Dupin L, Heyvaert V. 2004/2005. Geo-environmental investigation. In: Gasche $\mathrm{H}$, editor. The Persian Gulf Shorelines and the Karkheh, Karun, and Jarrahi Rivers: A Geo-Archaeological Approach. A Joint Belgo-Iranian Project. First Progress Report. Akkadica 125:2 (2004/2005):141-215.

Boehmer RM. 1991. 14C-Daten aus Uruk und Abydos Ägytisches (?) im Frühen Nordsyrien, Sumer und Elam. Mainz am Rhein: Verlag Philipp von Zabern. Baghdader Mitteilungen 22(1991):223-30.

Bronk Ramsey C. 2009. Bayesian analysis of radiocarbon dates. Radiocarbon 51(1):337-60.

Brückner H. 2003. Uruk-a geographic and paleo-archae- ologic perspective on a famous ancient city in Iraq. Bensheim: Georg-August University. Geo-Öko XXIV:229-48.

Burr GS, Edwards RL, Donahue DJ, Druffel ERM, Taylor FW. 1992. Mass spectrometric ${ }^{14} \mathrm{C}$ and U-Th measurements in coral. Radiocarbon 34(3):611-8.

Carter R, Crawford H. 2002. The Kuwait-British archaeological expedition to As-Sabiyah: report on the third season's work. Iraq 64:1-13.

Chen Z, Kavvas M, Ohara N, Anderson M, Yoon J. 2010. Impact of water resources utilization on the hydrology of Mesopotamian marshlands. Journal of Hydrologic Engineering 16(12): doi:10.1061/(ASCE)HE.19435584.0000208 .

Donahue DJ, Linick TW, Jull AJT. 1990. Isotope-ratio and background corrections for accelerator mass spectrometry radiocarbon measurements. Radiocarbon 32(2):135-42.

Fassbinder J, Becker H, van Ess M. 2005. Prospections magnétiques à Uruk (Warka). La cité du roi Gilgamesh (Irak). Dijon: Editions Faton SAS. Dossiers Archéologie 308:20-5.

Gasche H. 2004. The Persian Gulf shorelines and the Karakheh, Karun and Jarrahi rivers: a geo-archaeological approach. A Joint Belgo-Iranian Project. First progress report. Akkadica 125(2):141-215.

Godwin H, Suggate RP, Willis EH. 1958. Radiocarbon dating of the eustatic rise in ocean-level. Nature 181(4622):1518-9.

Heyvaert VMA, Baeteman C. 2008. A Middle to Late Holocene avulsion history of the Euphrates River: a case study from Tell ed-Dēr, Iraq, Lower Mesopotamia. Quaternary Science Reviews 27(25-26):240110.

Huot J-L, Calvet Y, Chevalier J, Forest J-D. 1981. II. Tell 
el 'Oueili. 1. Rapport préliminaire sur la deuxième champagne, (1978). Syria 58 (1-2):101-20.

IMOS [Iraqi Marshlands Observation System]. 2006. Iraqi Marshlands Observation System - UNEP Technical Report 2006. http://postconflict.unep.ch/publications/UNEP_IMOS.pdf.

Jull AJT, Burr GS, Beck JW, Hodgins GWL, Biddulph DL, Gann J, Hatheway AL, Lange TE, Lifton NA. 2006. Application of accelerator mass spectrometry to environmental and paleoclimate studies at the University of Arizona. In: Povinec P, Sanchez-Cabrera JA, editors. Radionuclides in the Environment 8:3-23.

Larsen CE. 1975. The Mesopotamia delta region: a reconsideration of Lees and Falcon. Journal of the American Oriental Society 95(1):43-57.

Münnich KO. 1957. Heidelberg natural radiocarbon measurements I. Science 126(3266):194-9.

Oates J, McMahon A, Karsgaard P, al-Quntar S, Ur J. 2007. Early Mesopotamian urbanism: a new view from the north. Antiquity 83(313):585-600.

Parrot A. 1948. Tello Vingt Campagnes de Fouilles (1877-1933). Paris: Editions Albin Michel.

Plaziat JC, Sanlaville P. 1991. Donnes recentes sur la sedimentation tardive dans la plaine de Larsa-Ouelli. In: Hout J-L, editor. 'Oueilli: Travaux de 1985. Paris: Editions Recherche sur les Civilizations. p 342-43.

Plaziat JC, Younis WR. 2005. The modern environments of Molluscs in southern Mesopotamia, Iraq: a guide to paleogeographical reconstructions of Quaternary fluvial, palustrine and marine deposits. Carnets de Géologie / Notebooks on Geology, Brest, Article 2005/01 (CG2005_A01).

Pournelle JR. 2003a. The littoral foundations of the Uruk state: using satellite photography toward a new understanding of 5th/4th millennium BCE landscapes in the Warka Survey Area, Iraq. In: Gheorghiu D, editor. Chalcolithic and Early Bronze Age Hydrostrategies. BAR International Series 1123. Oxford: Archaeopress. p 5-23.

Pournelle JR. 2003b. Marshland of cities: deltaic landscapes and the evolution of early Mesopotamian civilization [PhD dissertation]. Department of Anthropology, University of California, San Diego.

Pournelle JR. 2006-2011. Traces on the 'Ubaidian shore: Mid-Holocene eustasis, marine transgression, and urbanization in the Mesopotamian Delta (Iraq). Presented at: International Conference on the 'Ubaid. University of Durham, UK, April 2006; American School of Oriental Research Annual Meeting 2010Space, Place, and Landscape in the Old and New Worlds, Atlanta, Georgia, 17 November 2010 (updated); American Geophysical Union Annual Conference-The evolution of river systems since the Last Glacial Maximum and their interactions with human societies, December 2011 (updated).

Pournelle JR. 2007. KLM to Corona: a bird's-eye view of cultural ecology and early Mesopotamian civilization. In: Stone E, editor. Settlement and Society: Essays Dedicated to Robert McCormick Adams. Los Angeles: UCLA Cotsen Institute of Archaeology; Chicago: Oriental Institute. p 29-62.

Pournelle JR, Algaze G. 2012. Travels in Edin: deltaic resilience and early urbanism in greater Mesopotamia. In: Crawford $\mathrm{H}$, McMahon A, Postgate N, editors. Preludes to Urbanism: Studies in the Late Chalcolithic of Mesopotamia in Honour of Joan Oates. BAR International Series. Oxford: Archaeopress. In press.

Reimer PJ, Baillie MGL, Bard E, Bayliss A, Beck JW, Blackwell PG, Bronk Ramsey C, Buck CE, Burr GS, Edwards RL, Friedrich M, Grootes PM, Guilderson TP, Hajdas I, Heaton TJ, Hogg AG, Hughen KA, Kaiser KF, Kromer B, McCormac FG, Manning SW, Reimer RW, Richards DA, Southon JR, Talamo S, Turney CSM, van der Plicht J, Weyhenmeyer CE. 2009. IntCa109 and Marine09 radiocarbon age calibration curves, 0-50,000 years cal BP. Radiocarbon 51(4): 1111-50.

Safar F, Mustafa MA, Lloyd S. 1981. Eridu. Baghdad: Ministry of Culture and Information, State Organization of Antiquities and Heritage.

Southon J, Kashgarian M, Fontugne M, Metivier B, Yim WWS. 2002. Marine reservoir corrections for the Indian Ocean and Southeast Asia. Radiocarbon 44(1): 167-80.

Stuckenrath R, Ralph E. 1965. University of Pennsylvania radiocarbon dates VIII. Radiocarbon 7:187-91.

Ur J. 2010. Cycles of civilization in northern Mesopotamia, 4400-2000 B.C. Journal of Archaeological Research 18(4):387-431.

Valladas H, Evin J, Arnold M. 1996. Datation par la méthode du charbon 14 des couches Obeid 0 et 1 de Tell el Oueili (Iraq). In: Huot J-L, editor. Oueili: Travaux de 1987 et 1989. Paris: Editions Recherche sur les Civilizations. p 381-3.

Vogel JS, Southon JR, Nelson DE, Brown TA. 1984. Performance of catalytically condensed carbon for use in accelerator mass spectrometry. Nuclear Instruments and Methods in Physics Research B 5(2):289-93.

Wilkinson T. 2003. Archaeological Landscapes of the Near East. Tucson: University of Arizona Press.

Wright HT, Rupley ESA. 2001. Calibrated radiocarbon age determinations of Uruk-related assemblages. In: Rothman M, editor. Uruk Mesopotamia and Its Neighbors: Cross-Cultural Interactions in the Era of State Formation. Santa Fe: School of American Research Press. p 85-122. 